\title{
Russian cultural landscape: Theoretical and practical implications of the concept
}

\author{
B. Rodoman
}

Boris B. Rodoman, DSc (Geography). E-mail: bbrodom@mail.ru

Abstract. The author argues that the precise final definitions (recognized and universal) are often less important for scientists than the key features of the studied phenomena. Therefore, the author suggests to combine different concepts in order to get a working and temporary definition of the cultural landscape. The article presents this term as non-evaluative, mainly typological, non-taxonomic and 'real', which allows to consider its borders with the natural landscape as mobile, conventional and relative due to the fact that both landscapes are affected by human activities. The author describes factors and trends in the development of the cultural landscape, and regionalization as a tool to study and preserve it. The Russian cultural landscape is primarily determined by the interaction of the state with nature due to the obvious shortage of self-organized local communities. The author identifies endogenous (internal) and exogenous (external) factors in the (self)-development of the cultural landscape, which can be either stimulating or hindering. As the main features of the Russian cultural landscape the author considers its historically developed rhythm and ability to self-recover, which differ by country and region. Centuries of the military-colonial despotism and unprecedented centralization of the supreme power have turned the Russian space into a totalitarian landscape with the hypertrophied radial connections and the suppressed peripheral connections, which is embodied in the administrative-territorial division and determined the extraordinary social-economic, geographical, ecological and territorial polarization. The Russian landscape has a very specific feature - the so-called 'inner periphery', or hinterland (relative and ubiquitous): these are territories located closer to the country's cores than to its outskirts but with all negative features of the outskirts. This inner periphery plays an important role in the preservation and development of the natural landscape as a potential basis of the territorial ecological framework, but to ensure such a role we need a comprehensive cultural-historical regionalization.

Key words: landscape, cultural landscape, administrative-territorial division, etatization of landscape, anisotropic landscape, ecological potential of administrative borders, social-economic polarization, hinterland, inner periphery, regionalization, culturalhistorical areas.

DOI: 10.22394/2500-1809-2021-6-1-13-25

There is a widespread belief that before any discussions scientists must agree on the terms by providing their precise definitions. This rule is rooted in the geometry of Euclid as an example of an axiomatic scientific discipline. However, in the humanities and sometimes even in the natural sciences this rule does not work, because the features of the studied phenomena are more important than their final dictionary definitions which remain unattainable ideals. Therefore, 
14 to study the cultural landscape, I suggest the marginal analysis, i.e., the use of different concepts with the deliberate changes in their volтеовия umes and boundaries according to different criteria. Thus, the cultural landscape can be interpreted in different ways depending both on its relationships with such concepts as 'culture' and 'landscape' and on its evaluative or non-evaluative, individual or typological, general or taxonomic, continuous or discrete, universal or specific definitions, and also taking into account different degrees, directions, ways and goals of the cultural landscape's metaphorizing in different scientific disciplines and public discourses.

The concept 'landscape' implicitly used in the article is one of many possible interpretations; thereby, I consider it rather working and temporary than recognized and universal for the professional discourse. I use the term 'cultural landscape' as if I fully understand its content and meaning, but actually I do not care about its clear final definition. I use the term 'cultural landscape' as non-evaluative, mainly typological, non-taxonomic and 'vulgarly real', which is quite similar to the term 'anthropogenic landscape' (Milkov, 1973). I believe that landscape (without any adjectives) is a material part of the human environment (space), which consists of solid and liquid earthly bodies, has mainly a multi-layered structure, is observable and includes natural and artificial elements. In the non-evaluative perspective, the cultural landscape (as not opposed to the 'uncultured landscape') developed under the decisive influence of human activities: in this sense, the cultural landscape differs from the natural landscape, but the boundaries between two concepts and two corresponding objects are mobile, conventional and relative. There are very few purely natural landscapes not affected by human activities at least in the distant past; however, when in the mountains or taiga, we see that we did not affect those essential features of the environment that are decisive for our behavior. An intermediate position between the wild nature and the urban environment is taken by suburban, rural, agricultural landscapes together with wastelands and landfills recaptured by flora and fauna.

My descriptions of the Russian cultural landscape follow the classical positivist real geography: I do not care about its images in the minds of ignorant people or about myths produced by their absurd representations; I do not consider the cultural landscape as a text and do not study texts about it; I do not understand how the entire cultural landscape on most of the earth's land differs from the natural-anthropogenic landscape in general. Nevertheless, under the contemporary postmodernist trends, I admit that my interpretation of the Russian cultural landscape is personal (based on my experience and impressions rather than scientific sources), and, if accepted by some readers, can turn into a myth. I hope that this clarification will satisfy those readers who believe that there is no objective reality or unconditional truth, but only narratives and discourses. 
The cultural landscape seems to be the result of the interaction between society and natural environment, which sounds philosophically attractive but is hardly applicable to the Russian situation. The Russian landscape is primarily the result of the interaction between nature and the state rather than society (Kagansky, 2009). In Russia, there is no society as an actor that opposes the state and enters into contractual relationships with it, and there are very few self-organized local communities that interact with the elected local government and environment deliberately and in solidarity. In Russia, the role of local residents in the development of their native - urban, rural or wild - landscape has steadily declined during the 2oth century. All changes in landscape are usually 'external' and unexpected - both in their essence and consequences.

Not every change in landscape and society can be called development - on the contrary, there are many external influences that hinder development. The historical changes in the cultural landscape are determined by endogenous (internal) and exogenous (external) factors: 'internal' and 'external' in the purely geographical, territorial meaning - the former as located within the considered area, and the latter as coming from the outside. One of the internal factors is the smooth and long-term self-development of the cultural landscape, which in the past centuries was almost unobservable during one human life, because such a self-development was the result of the wellknown interaction between nature and the specific, limited, relatively small part of society - a group, community or ethnos. In the smooth autonomous evolution of the cultural landscape, there are two mechanisms - quasi-natural selection (according to Darwin) and nomogenesis (Berg, 1922). The selection improves household items, buildings, applied and visual arts, while nomogenesis - transport networks (Rodoman, 2002), which is confirmed by the study of their evolutionary morphology (Tarkhov, 2005).

The 'natural', 'normal' self-development of the cultural landscape is sooner or later interrupted by external factors, mostly unexpected and violent - natural disasters, conquests, state reforms and reorganizations. For instance, in the 21st century, the countryside of the so-called Central Russia (more precisely, of the western part of its central area) experienced at least 25 terrible shocks: Stolypin reforms, first war with Germany, October Revolution, post-revolutionary devastation, civil war, peasant uprisings, dispossession of kulaks and collectivization, second war with Germany, post-war devastation, integration of collective farms, transformation of some of them into state farms, elimination of 'unpromising' rural settlements, 'land reclamation' (in fact, land deterioration), chemicalization in agriculture, disappearance of country dirt roads, dismantling of narrow-gauge railways, various market reforms, privatization and confusion with

\section{B. Rodoman}

Russian cultural landscape:

Theoretical and practical implications of the concept 
property rights, collapse of collective and state farms, collapse of flax growing and grain production, attempts and failure to support private теория farmers, economic crisis and devastation of the 19gos, development of cottage construction by townspeople, contamination and destruction of old forests, and overgrowing of agricultural lands with forests. The fact that after all these shocks there is still some life in the Russian rural hinterland is a miracle rather than a regularity.

In the southeast of European Russia, not directly affected by the World War II, the devastation of the village was prevented by the attachment of many indigenous non-Russian peoples to their small motherland. There are reasons to believe that the ethnic-confessional heterogeneity of the Volga-Ural Region, officially proved by the presence of ethnic republics in the Russian Federation, together with the patriarchal way of life, family-kinship cooperation and division of labor saved the countryside from complete desolation (Nefedova, 2003).

Thus, under some external factors, the quasi-natural evolution of the cultural landscape can be interrupted, but resumes after the administrative influence ceases and the reform meets the usual and expected fate of its predecessors according to the 'law of Chernomyrdin' ('we wanted the best, but it turned out as always'). After repeated shocks, the continuity of development is broken, most of previous achievements are lost, and much has to be started anew.

\section{Features of the Russian landscape}

The Russian landscape is not only a passive victim of the state arbitrariness, but also an avenger. Moscow is unusually lucky - it has never suffered from natural disasters (like destructive earthquakes) other than weather disasters (hurricanes, extreme colds and heats, smoke from fires and floods, although, after the Moscow River was put under control, severe floods as in the first decade of the 2oth century are very unlikely today). However, in many other regions the situation is worse: although the inevitable future revenge of nature for unforgivable mistakes is often delayed and not obvious, the epiphany always comes albeit too late. For the construction in deltas and floodplains, on drainage slopes and mountainsides with streams, which were imprudently deprived of forests, and in the seismically hazardous areas people pay with destructions from floods, avalanches, mudflows, landslides and earthquakes. However, these well-known natural disasters are determined by the irrational land use, but I am interested not in the nature's revenge, but in the whole cultural landscape's revenge for our voluntarism. The cultural landscape is responsible for social calamities as a response to the arbitrariness of sovereigns and officials.

Moreover, regions differ by the historically developed landscape rhythms (Rodoman, 2002). For instance, in Western Europe this rhythm is more fractional (high-frequency), while in Siberia it is less 
fractional (low-frequency) than in the Moscow Region. Under the evolutionary self-development, the anthropogenic superstructure of the cultural landscape harmonizes with its natural basis, but under interventions the resonance is often broken. Thus, the opposition to the traditional landscape led to the failure of three main Russian reforms - of Alexander II, P.A. Stolypin and E.T. Gaidar: these reforms were not completed and turned out to be counterproductive.

The cultural landscape is very inert, which often prevents its deprivation of the ability to self-recover. The location, size and shape of lands hinder changes in their use: in the countryside, the state failed to destroy the peasant-landlord landscape by replacing it with a uniform distribution of small estates and farms in the Western-European way. Contemporary parcels are household and garden plots with cottages, and latifundias are unused fields and wastelands that surround plots and wait for new plowing or construction but are doomed to long desolation due to being too far from cities. Land reforms were disasters for rural residents and inevitably failed, because it is impossible to quickly move fields, gardens and houses. After every reform the country returned to the pre-reform situation that even deteriorated, because the population responded by the revival of archaic practices.

The Soviet rural collectivization turned out to be the third wave of enslavement, and the post-Soviet privatization - the fourth (the first wave ended in the middle of the $17^{\text {th }}$ century, and the second wave began and reached its heights in the 18th century). After the abolition of serfdom, the former landlord peasants and their descendants were relatively free for only 60 years and then became Soviet serfs without passports. Today residents of small towns in Central Russia, of single-industry towns, industrial communities and rural settlements are economically less free than the landlord peasants on quitrent not to mention the state peasants before 1861. Moreover, in most parts of tsarist Russia, there was no serfdom, while today in Russia nobody can start a 'small business' without a powerful administrative-criminal protection.

Nevertheless, not all state attacks on the cultural landscape were destructive. A good example is the unjustly forgotten 'Great Stalin's (actually Dokuchaev's) plan for the transformation of nature', despite the fact that the field-protective forest belts did not solve their main tasks sufficiently - to protect fields from dry winds and to increase productivity, because these belts were designed as huge rectangles and did not take into account the relief and river networks. This fact was proved by the geographer D.L. Armand (1961), who was a talented engineer and calculated, albeit too late, the parameters of the field-protective forest belts. His work was also forgotten after the political wind from Moscow blew towards northern Kazakhstan - the 'virgin lands'.

However, albeit in a perverted form, the 'transformation of nature' improved the ecological situation in sparsely forested and woodless
17

B. Rodoman

Russian cultural

landscape:

Theoretical

and practical

implications of the concept 
18 areas (which does not apply to the destruction of large rivers by hydraulic power systems and to the transformation of the Volga river теория into a cascade of 'swamp-reservoirs'). The wide forest belts between fields and along roads improved the landscape and its biodiversity. Today there are no such complex reclamations, and forest belts are cut down and built up with cottages. The Russian quasi-market economy does not seem to possess mechanisms for improving the cultural landscape. I do not think that we need a totalitarian regime to mobilize people for good deeds, because there are successful government programs for the landscape transformation under non-authoritarian regimes (for example, in the Netherlands and Israel).

\section{Trends in the development of the Russian landscape}

Centuries of the military-colonial despotism and unprecedented centralization of the supreme power have radically changed the Russian space and turned it into a totalitarian landscape (Rodoman, 2002) - a material-spatial embodiment of the service-distribution, command-administrative economy and autocratic-bureaucratic hierarchy, in which radial connections (center-periphery) are hypertrophied, while all peripheral connections are suppressed. I call this striking difference between radial and other connections the centric anisotropy (there are many anisotropies typical for the landscape). Radial connections reproduce or reflect the so-called 'vertical of power', while peripheral connections reveal the lack or shortage of cooperation between elements subordinate to the center.

The Russian totalitarian landscape is embodied in the administrative-territorial division which consists of the universal units of social life similar to houses or apartments. There are many types of departmental regionalization (Kordonsky, 2010), but all of them are congruent with the national administrative-territorial division. The cultural landscape is a reflection of relationships between people; therefore, in Russia, the infrastructure, routes of transport and migration, and interpersonal ties reflect primarily the bureaucratic hierarchy (main roads were previously the routes of officials and couriers).

The hopes that after the 1990 s political and market reforms the Russian society would quickly move from the inert hierarchical structure to a more flexible network society did not come true. There are developing Internet networks, but in real life centralization and bureaucratization have increased, which leads to the further etatization of landscape. The Russian centralized anisotropic landscape is universal and reproduces at all levels of the territorial hierarchy - in regions ('subjects of the Russian Federation'), cities and rural areas.

Due to the continuing concentration of all activities in cities and suburbs and to the relative isolation of regions, whose heads do not 
cooperate but only follow instructions from Moscow, there are no local transport routes at the borders of administrative regions and districts, which creates zones of depopulation and economic decline. The higher the taxonomic rank of the administrative region, the wider the zone of desolation along its borders. The widest zone of desolation is along the state borders of the Russian Federation.

There are unused lands on both sides of the border between Russia and the CIS countries, while between Russia and the EU countries - mostly on the Russian side. Such depressive border strips have increased in Russia despite all global trends and dreams about the close regional cooperation and fruitful international cross-border cooperation (Barinov, 2012). However, every cloud has a silver lining: these strips help to preserve the gradually reviving natural landscape, which allows to include them into the econet - the global network of specially protected natural areas (in the Internet, the word 'econet' often means the 'ecological Internet' which has nothing to do with ecology). The spontaneous econetization of administrative borders and their significant ecological potential are a unique and specific feature of the post-Soviet space, which does not seem to have analogues outside this space and, therefore, is unknown to Western geography.

The Russian extraordinary social-economic polarization (especially property inequalities) has a specific integral part - the geographical, ecological, territorial polarization, i.e., the growing contradictions between the more successful and prosperous urbanized cores of the country and the depressive areas paradoxically located not so much on its geographic outskirts as everywhere inside its cores - in the socalled glubinka. This word has already become a scientific term (Russian Glubinka..., 2012) and, probably, will take its rightful place in international dictionaries like other 'primordially Russian' concepts (intelligentsia, dacha, raspoutitsa - flooded country roads), although glubinka is a partial synonym for the term 'intra-periphery' (Rodoman, 1987) and 'inner periphery' (Kagansky, 2012).

The inner periphery of some centric area consists of territories located closer to its center than to its outskirts; however, these territories have such features of the outskirts as poor transport accessibility, slow development, obvious lags in many social-economic fields, and archaic characteristics of landscape and everyday life. In the simplest and universal (triangular-hexagonal) geometric model of regionalization and communications, the inner periphery is located in the cells of the transport network or, which is the same, at the borders of regional junctions (Rodoman, 1999). However, in real life, the transport factor is often insufficient for the development of intra-periphery, and other factors of internal peripheralization play their role: natural conditions, ethnic composition of the local population, economic-social history of the region. For instance, the largest inner periphery of the Russian Empire developed in the
B. Rodoman

Russian cultural

landscape:

Theoretical

and practical

implications of the concept 
20 19th century in the Petersburg-Moscow-Warsaw railway triangle and consisted of the northwestern provinces of Russia and a part of теория Belarus. Many иyеzd towns were cut off from railways and fell into decay. In the 2oth century, the rare and belated highways played the same role of the 'destroyer of backwoods'. Most small villages disappeared due to the lack of satisfactory transport routes with the 'civilized' outside world.

The key features of the inner periphery, especially important in the specific and unique conditions of Russia, are its relativity and ubiquity: one cannot say for sure and show on the map peripheral and central areas, because such 'statuses' of territories depend on the chosen 'coordinate system'. In Russia, the administrative-territorial division is the main coordinate system; therefore, one can easily find as many types of centrality-peripherality as there are levels in this division: internal periphery of regions, municipal districts, and so on. In addition, there are unofficial, implicit regional junctions such as the latent, non-existent districts that were once official (for example, the Tarsky district in the Omsk Region) or that have never been official but were partly identified as important nodes, for example, in the famous geographical zoning of E.E. Leizerovich (2004). The ubiquity of the inner periphery is determined by its relativity: for almost any geographical point one can find objects for which it will be central or peripheral.

In my works (Rodoman, 2002, 2006), the Russian inner periphery is presented as playing an important role in the preservation and development of the natural landscape without large funding. The traditional economic approach focusing on investment, employment and jobs is irrelevant here, because the wildlife restoration (although not in the best and desired form) goes by itself, and we should not interfere with it. The inner periphery is a potential basis of the territorial ecological framework - any artificial secondary colonization of the Russian non-black-earth inner periphery outside the suburban areas will fail. The few remaining permanent native residents of this hinterland, who are truly attached to their small motherland and want to keep their traditional way of life, should be given the rights of aborigines regardless of their ethnicity and subsidies for the sake of preserving nature, culture, land, and Russia.

Thus, in the 'geographically-politically correct perspective', the Russian inner periphery is not only a sick and decaying land that needs to be cured by the traditional economic methods, but also a concentration of ecological opportunities for the preservation and prosperity of the natural landscape. The discovery of the anisotropic totalitarian landscape, devastated border strips, inner periphery and their ecological potential are important achievements of the Russian social-economic and theoretical geography, which are based on the unbiased study of one's country, i.e., on the study not focused on some fashionable borrowed concepts. 
Regionalization is one of the most important methods in geographical sciences, and plays the same role in geography as periodization in history and classification in zoology and botany. Regionalization allows to define and describe specific areas of land accurately and unambiguously, thus, representing the territory completely, without any gaps. Regionalization is also the highest, synthetic form of thematic mapping (Rodoman, 2007). There are many thematic maps made by the differentiated/qualitative/colored-background method in the natural-geographical sciences: for instance, the natural landscape of the former USSR was studied and depicted on maps. The physical-geographical regionalization can and should serve as a model for the cultural landscape, regionalization, but the question is what should be the territorial units of the cultural landscape regionalization, i.e., what 'natural-cultural territorial complexes' should be taken as 'cells' of the area. Cultural geographers cannot compare with naturalists in the complex taxonomic pyramids; therefore, we should start with the simplest self-evident models such as presenting the cultural landscape as a combination of the wellknown cultural-historical areas as its primary and largest units.

Ecologists hope to preserve the natural landscape as the econet-a continuous network of wide 'green corridors' that cross a densely populated urbanized territory. This is the basis of my conceptual project of the 'polarized biosphere' based on the Russian spatial specifics (Rodoman, 2002). Due to the hyper-centralization of the Russian space, there are still strips of the wilder natural landscape on the borders of regions, republics and their municipal districts - with no cross-border communications or local highways. The borders of the Moscow Region are an obvious exception to this rule due to its being not only one of the core regions at the national/federal level, but also the core of the Russian state; therefore, on the borders of the Moscow Region with the outside world rather interaction than barrier functions prevail. From the outside of the Moscow Region borders, there are concentrations of objects and activities that strive to get closer to the capital but cannot enter the metropolitan area.

The forest-park protective belts grow by themselves on the administrative borders due to the specifics of the administrative-territorial division. The development of the econet on the administrative borders is a wonderful, convincing example of the 'sleep-mode' benefits: to achieve a good goal (self-restoration of nature) we need a gracious lack of action instead of purposeful activities.

In Russia, until the World War II, rural settlements location followed the morphological structure of the natural landscape (Solntsev, 1962), which differed by natural area (Gvozdetsky, Zhuchkova, 1963). Thus, on the Moscow Upland, northwest of Moscow, villages were built on moraine hills, while on the erosional plain, south of Moscow, villages were built in the valleys of small rivers. In general, in

B. Rodoman

Russian cultural landscape:

Theoretical and practical implications of the concept 
22 the Moscow Region, there were areas of different types of rural settlement, which corresponded to natural (physical-geographical) areтеория as of the same size. In the middle of the 2oth century, this traditional system of rural settlement was destroyed by the mass distribution of land to the townspeople for gardens that were immediately turned into summer dacha villages. Collective, state and forest farms willingly got rid of lands that hindered the achievement of the plan indicators. In the suburbs, the so-called 'garden partnerships' occupied the lands of the ecological framework - forest edges and damp clearings, floodplains, riverheads and high moors. The cottage villages suitable for year-round living, which became widespread at the end of the 2oth century, inherited the same ecophobic patterns of location. The townspeople have built up such types of land on which the local peasants had not settled before. The ecological consequences of such settlement patterns were harmful not only for wild flora and fauna, but also for people (destruction of surface and ground water runoffs, pollution and degradation of forests, etc.). Thus, the traditional cultural-historical provinces are destroyed by suburbanization and transformation of the former village into a second place to live for the townspeople, who do not follow many previous patterns of rural construction, do not reproduce the traditional organization of the rural settlement with houses built along the river, do not clean or preserve the old village ponds.

I believe that the cultural-historical regionalization of the cultural landscape, which makes the scientific geography possible. Unfortunately, architects and geographers are not interested in the cultural landscape regionalization, and the corresponding regions disappear - unknown, unexplored and unmapped.

The Latvian Ethnographic Open-Air Museum in Riga is one of the oldest in Europe and copies the Stockholm Skansen Museum in grouping its exhibits according to the historical regions of Latvia - Vidzeme, Kurzeme, Zemgale and Latgale. In Soviet times, Moscow tried to intervene in this non-routine (for the USSR) situation and to change this grouping by the class division, so that the museum would present typical courtyards of the poor, middle peasants and kulaks, but I was lucky to see the original regional exposition. The question is whether we can identify historical areas in Russia.

Unlike other European countries, Russia lacks historical provinces (like Normandy and Provence in France, Vidzeme and Kurzeme in Latvia). Russians identify themselves by administrative units (regions, republics) and even name cattle breeds by province (for instance, Yaroslavl and Kostroma breeds). Surprisingly, neighboring Ukraine, quite close to Russia in culture, consists of historical regions (Volyn, Podillia, etc.) that can be the basis of both its possible federal structure (similar to Germany and Austria) and its disintegration (they are presented in Kiev, like in Riga, in the open-air museum). A 
similar museum in New Moscow would present the national cultural and natural heritage by administrative region.

Thus, for classifying and making an inventory of the Russian cultural landscape, including the purpose of preserving the national cultural heritage, scientists should identify and model special cultural-historical areas that do not necessarily coincide with the administrative or natural divisions. I have repeatedly suggested and described such a model based on three regions of the traditional rural landscape around Moscow, which was almost destroyed by cottage villages (Rodoman, 2011). I believe that each zone should have at least one protected-landscape museum-reserve and be presented by a preserved typical rural area - one village or a bunch of villages with the surrounding land, including forests and reservoirs. Certainly, the key and unique feature of the Russian cultural landscape is the huge role of the authoritarian state in its development: the unilateral influence of the government on landscape and population without any feedback, colonial methods of the multiple development of the same territory, landscape polarization, centric anisotropy of space, growth of the inner periphery, devastation of border strips, and spontaneous restoration of 'wild nature'. The last three processes can be used to restore the favorable natural landscape and to help Russia to choose the environmental specialization in the global economy. To identify and preserve the samples of the cultural and natural heritage we need a universal scientific regionalization of the cultural landscape.

\section{References}

Armand D.L. (1961) Fiziko-geograficheskie osnovy proektirovaniya seti polezashchitnykh lesnykh polos [Physical-Geographical Foundations of Designing a Network of Forest Protective Belts], Moscow: Izd-vo AN SSSR.

Barinov S.L. (2012) Novoe zapadnoe pogranichie RF: vliyanie granits na kommunikatsiyu naseleniya [The New Western Border Area of the Russian Federation: Influence of Borders on Communication]: Avtoref. diss. k.g.n. Moscow: IG RAN.

Berg L.S. (1922) Nomogenez, ili Evolyutsiya na osnove zakonomernostey [Nomogenesis, or Evolution Based on Regularities], Petrograd: Glz.

Gvozdetsky N.A., Zhuchkova V.K. (Eds.). (1963) Fiziko-geograficheskoe rayonirovanie Nechernozemnogo tsentra [Physical-Geographical Zoning of the Non-Black-Earth Center], Moscow: Izd-vo MGU.

Kagansky V.L. (2009) Prirodno-gosudarstvenny landshaft Severnoy Evrazii: teoreticheskaya geografiya [Natural-state landscape of Northern Eurasia: theoretical geography]. Sotsialno-ekonomicheskaya geografiya: traditsii i sovremennost, Moscow-Smolensk: Oikumena, pp. 78-100.

Kagansky V.L. (2012) Vnutrennyaya periferiya - novaya rastushchaya zona kulturnogo landshafta Rossii [Inner periphery - a new increasing zone of the Russian cultural landscape]. Izvestiya RAN. Seriya geograficheskaya, no 6.

Kordonsky S.G. (2010) Rossiya. Pomestnaya federatsiya [Russia. Federation of Estates], Moscow: Izd-vo "Evropa”. 
24 Leizerovich E.E. (2004) Ekonomicheskie mikrorayony Rossii (setka i tipologiya) [Economic Micro-Districts of Russia (Grid and Typology)], Moscow: Trilobit.

тЕория Milkov F.N. (1973) Chelovek i landshafty: ocherki antropogennogo landshaftovedeniya [Man and Landscapes: Essays on the Anthropogenic Landscape Science], Moscow: Mysl.

Nefedova T.G. (2003) Selskaya Rossiya na pereputie: Geograficheskie ocherki [Rural Russia at the Crossroads: Geographical Essays], Moscow: Novoe izdatelstvo.

Rodoman B.B. (1987) Ekspressny transport, rasselenie i okhrana prirody [Express transport, resettlement and nature protection]. Metody izucheniya rasseleniya, Moscow: IGAN, pp. 44-54.

Rodoman B.B. (1999) Territorialnye arealy i seti. Ocherki teoreticheskoy geografii [Territorial Areas and Networks. Essays on Theoretical Geography], Smolensk: Oikumena.

Rodoman B.B. (2002) Polyarizovannaya biosfera [Polarized Biosphere], Smolensk: Oikumena.

Rodoman B.B. (2006) Ekologicheskaya spetsializatsiya Rossii v globaliziruyushchemsya mire (Proekt nestandartnogo resheniya) [Environmental specialization of Russia in the globalizing world (A draft of the non-standard solution)]. Obshchestvennye nauki $i$ sovremennost, no 2.

Rodoman B.B. (2007) Geografiya, rayonirovanie, kartoidy [Geography, Zoning, Spatial Theoretical Maps], Smolensk: Oikumena.

Rodoman B.B. (2011) Traditsionny kulturny landshaft: osnovnye problemy tipologii, rayonirovaniya i voobrazheniya [Traditional cultural landscape: Main challenges for typology, zoning and imagination]. Mezhdunarodny zhurnal issledovaniy kultury, no 4

Rossiyskaya glubinka - modeli i metody izucheniya [Russian Glubinka - Models and Methods of Study] (2012), Moscow: IG RAN.

Solntsev N.A. et al (Eds.) (1962). Morfologicheskaya struktura geograficheskogo landshafta [Morphological Structure of the Geographical Landscape], Moscow: Izd-vo MGU.

Tarkhov S.A. (2005) Evolyutsionnaya morfologiya transportnykh setey [Evolutionary Morphology of Transport Networks], Smolensk-Moscow: Universum.

\section{Российский культурный ландшафт: теоретические и практические возможности концепции}

Борис Борисович Родоман, доктор географических наук. E-mail: bbrodom@mail.ru

Аннотация. Автор полагает, что в науке точные окончательные определения (общепризнанные и универсальные) часто менее важны, чем понимание ключевых характеристик рассматриваемых феноменов. Поэтому для изучения культурного ландшафта автор предлагает сочетать разные понятия, меняя их содержание и концептуальные границы так, чтобы получить рабочее и временное определение культурного ландшафта. В статье этот термин представлен как безоценочный, преимущественно типологический, нетаксономический и "реальный", что позволяет считать его границы с понятием природного ландшафта подвижными, относительными и условными - решающее воздействие на оба ландшафта оказала человеческая деятельность. Автор обозначает факторы и тенденции в развитии культурного ландшафта и предлагает районирование как инструмент его изучения и сохранения. Характер российского культурного ландшафта обусловлен в первую очередь взаимодействием государства с природой - в силу очевидного недостатка самоорганизованных местных сообществ. Автор выделяет эндогенные (внутренние) и экзогенные (внешние) факторы (само)развития культурного ландшафта, которые могут как стимулировать, так и тормозить его. В качестве главных особенностей российского культурного ландшафта в статье представлены его исторически сложившийся ритм и способность к самовосстановлению, которые различаются по странам и регионам. Столетия военно-колониального деспотизма и беспрецедентной централизации верховной власти превратили российское 
пространство в тоталитарный ландшафт с гипертрофированными радиальными

и подавленными периферийными связями, что воплотилось в административнотерриториальном делении страны и обусловило ее чрезмерную социальноэкономическую, географическую, экологическую и территориальную поляризацию. Российский ландшафт имеет одну очень особенную черту - так называемую "Внутреннюю периферию", или глубинку (относительную и повсеместную): это территории, расположенные ближе к центрам страны, чем к ее окраинам, но обладающие всеми негативными чертами окраин. Внутренняя периферия играет важную роль в сохранении и развитии природного ландшафта, выступая потенциальной опорой территориального экологического каркаса, но для обеспечения этой роли необходимо проводить комплексное культурноисторическое районирование страны.

Ключевые слова: ландшафт, культурный ландшафт, административнотерриториальное деление, этатизация ландшафта, анизотропный ландшафт, экологический потенциал административных границ, социально-экономическая поляризация, глубинка, внутренняя периферия, районирование, культурноисторические области. 